Correction

\title{
Correction: Mudie et al. In Vitro-In Silico Tools for Streamlined Development of Acalabrutinib Amorphous Solid Dispersion Tablets. Pharmaceutics 2021, 13, 1257
}

\author{
Deanna M. Mudie *(D), Aaron M. Stewart (D), Jesus A. Rosales ${ }^{\dagger}$, Molly S. Adam, Michael M. Morgen (D) \\ and David T. Vodak
}

check for updates

Citation: Mudie, D.M.; Stewart, A.M.; Rosales, J.A.; Adam, M.S.; Morgen, M.M.; Vodak, D.T. Correction: Mudie et al. In Vitro-In Silico Tools for Streamlined Development of Acalabrutinib Amorphous Solid Dispersion Tablets. Pharmaceutics 2021, 13, 1257. Pharmaceutics 2021, 13, 2059. https://doi.org/10.3390/ pharmaceutics13122059

Received: 19 November 2021 Accepted: 24 November 2021 Published: 2 December 2021

Publisher's Note: MDPI stays neutral with regard to jurisdictional claims in published maps and institutional affiliations.

Copyright: (C) 2021 by the authors Licensee MDPI, Basel, Switzerland. This article is an open access article distributed under the terms and conditions of the Creative Commons Attribution (CC BY) license (https:// creativecommons.org/licenses/by/ $4.0 /)$.
Global Research \& Development, Lonza, Bend, OR 97703, USA; aaron.stewart@lonza.com (A.M.S.); rosaleja@uw.edu (J.A.R.); molly.adam@lonza.com (M.S.A.); michael.morgen@lonza.com (M.M.M.); david.vodak@lonza.com (D.T.V.)

* Correspondence: deanna.mudie@lonza.com

+ Current address: Pharmaceutics Department, University of Washington, Seattle, WA 98195, USA.

The authors wish to make the following corrections to this paper [1].

There was an error in the original article in the Abstract section, where it was stated that the absolute average fold error (AAFE) of the in silico predictions for $\mathrm{AUC}_{0 \text {-inf }}$ for Calquence + famotidine was $\approx 3$. A correction has been made to the abstract section: "In silico simulations of the HPMCAS-H ASD tablet and Calquence capsule provided good in vivo study prediction accuracy using a bottom-up approach (absolute average fold error of $\left.\mathrm{AUC}_{0 \text {-inf }}<2\right)^{\prime \prime}$.

There was an error in the original article in the Results section (Section 3.6, paragraph 1), where it was stated that AAFE of the in silico predictions for $\mathrm{AUC}_{0 \text {-inf }}$ for the Calquence capsule + famotidine treatment was not $<2$. A correction has been made in the original article in the Results section (Section 3.6, paragraph 1): "The AAFE of the in silico predictions for $\mathrm{AUC}_{0 \text {-inf }}, \mathrm{C}_{\max }, \mathrm{T}_{\max }$, and $\mathrm{C}_{\mathrm{p}}$ versus time for all formulation treatments were $<2$-fold (ideal value $=1$ ) with the exception of $C_{p}$ versus time for the Calquence capsule + famotidine treatment, indicating that the in silico prediction framework is sufficient for simulating acalabrutinib blood plasma concentrations within this in vivo study".

In the original article, there were mistakes in Table 4 as published, where AAFE for $\mathrm{AUC}_{0 \text {-inf }}$ for the Calquence capsule + pentagastrin was listed as 1.2 and $\mathrm{AAFE}$ for $\mathrm{AUC}_{0 \text {-inf }}$ for Calquence capsule + famotidine was listed as 3.6. The corrected Table 4 appears below.

Table 4. Noncompartmental analysis comparing simulated (sim) versus observed (obs) data for all formulation treatments in the dog study. Absolute average fold error (AAFE) was calculated for $\mathrm{AUC}_{0 \text {-inf }}, \mathrm{C}_{\max }, \mathrm{T}_{\max }$, and $\mathrm{C}_{\mathrm{p}}$ versus time to determine the accuracy of the in silico prediction exercise (ideal value $=1$ ).

\begin{tabular}{|c|c|c|c|c|c|c|c|c|c|c|}
\hline \multirow{2}{*}{ Formulation } & \multicolumn{2}{|c|}{$\begin{array}{r}\mathrm{AUC}_{0-\mathrm{inf}} \\
\text { (ng h/mL) }\end{array}$} & \multicolumn{2}{|c|}{$\begin{array}{c}\mathrm{C}_{\max } \\
(\mathrm{ng} / \mathrm{mL})\end{array}$} & \multicolumn{2}{|c|}{$\mathrm{T}_{\max }(\mathrm{h})$} & \multicolumn{4}{|c|}{ AAFE } \\
\hline & Obs & Sim & Obs & Sim & Obs & Sim & $\mathrm{AUC}_{0 \text {-inf }}$ & $\mathrm{C}_{\max }$ & $T_{\max }$ & $\begin{array}{l}\mathrm{C}_{\mathrm{p}} \text { vs. } \\
\text { Time }\end{array}$ \\
\hline $\begin{array}{l}\text { ASD tablet, } \\
\text { pentagastrin }\end{array}$ & 8161 & 9766 & 3332 & 3727 & 0.9 & 0.9 & 1.2 & 1.2 & 1.6 & 1.3 \\
\hline $\begin{array}{l}\text { ASD tablet, } \\
\text { famotidine }\end{array}$ & 7579 & 9555 & 3443 & 3508 & 0.9 & 1.6 & 1.3 & 1.2 & 1.8 & 1.6 \\
\hline $\begin{array}{l}\text { Calquence } \\
\text { capsule, } \\
\text { pentagastrin }\end{array}$ & 8365 & 8607 & 4480 & 3110 & 0.8 & 0.9 & 1.1 & 1.4 & 1.3 & 1.3 \\
\hline $\begin{array}{l}\text { Calquence } \\
\text { capsule, } \\
\text { famotidine }\end{array}$ & 3112 & 3096 & 355 & 648 & 1.6 & 1.2 & 1.6 & 1.9 & 1.7 & 3.0 \\
\hline
\end{tabular}


The authors apologize for any inconvenience caused and state that the scientific conclusions are unaffected. The original publication has also been updated.

\section{Reference}

1. Mudie, D.M.; Stewart, A.M.; Rosales, J.A.; Adam, M.S.; Morgen, M.M.; Vodak, D.T. In Vitro-In Silico Tools for Streamlined Development of Acalabrutinib Amorphous Solid Dispersion Tablets. Pharmaceutics 2021, 13, 1257. [CrossRef] [PubMed] 